\title{
DE EVITA A EVA LOPO, DO ROMANCE DE LÍDIA JORGE AO CINEMA DE MARGARIDA CARDOSO: A TRANSPOSIÇÃO DE UMA PERSONAGEM INSTRANSPONÍVEL
}

\author{
Camila Canali Doval \\ Pontifícia Universidade Católica do Rio Grande do Sul
}

\begin{abstract}
Resumo: O presente artigo teve seu argumento principal suscitado pela fala da escritora Lídia Jorge em palestra ministrada no dia 28 de setembro de 2012 na Pontifícia Universidade Católica do Rio Grande do Sul. A autora falou à plateia sobre a adaptação cinematográfica do seu romance A costa dos murmúrios (1988), realizada pela diretora, também portuguesa, Margarida Cardoso (em 2004). Questionada a respeito do olhar feminino sobre a guerra colonial - uma das tantas perspectivas temáticas que pode ser pinçada da obra —, Lídia confrontou as duas obras, argumentando que o livro não defende um olhar inocente das mulheres sobre a guerra, enquanto que na trama cinematográfica há a perspectiva de isenção de culpa. Tendo em vista tal ponto de partida, esta análise se propõe a investigar a forma com que a diretora Margarida Cardoso interpretou e transpôs a atuação das mulheres retratadas na obra original, diante do conflito enfocado no livro, trazendo para o foco a protagonista Eva Lopo, Evita.
\end{abstract}

Palavras-chave: A costa dos murmúrios. Literatura portuguesa. Cinema português. Lídia Jorge. Transposição.

\section{Inspiração}

No dia 28 de setembro de 2012, às 19h30, no auditório do prédio 9 da Pontifícia Universidade Católica do Rio Grande do Sul, a escritora portuguesa Lídia Jorge participou do evento promovido pela editora Leya "Encontro com Lídia Jorge".

Ao término de sua fala, Lídia respondeu questões formuladas pela plateia, e uma

\section{c)} (i) () $\Theta$

BY NC ND Esta obra está licenciada sob uma Licença Creative Commons.

\footnotetext{
* Doutoranda em Teoria da Literatura pela Pontifícia Universidade Católica do RS (2012/ ); Mestre em Teoria da Literatura no eixo da Escrita Criativa pela Pontifícia Universidade Católica do RS - PUCRS (2010/2012); Especialista em Estudos Linguísticos do Texto pela Universidade Federal do Rio Grande do Sul - UFRGS (2009/1) e Licenciada em Letras - Língua Portuguesa e Literaturas de Língua Portuguesa pela Universidade Luterana do Brasil - ULBRA (2006/2). olsista CNPq.
} 
delas se referia à adaptação cinematográfica do seu romance A costa dos murmúrios (1988), realizada pela diretora, também portuguesa, Margarida Cardoso (em 2004). A pergunta convergia para o olhar feminino sobre a guerra - uma das tantas perspectivas temáticas que pode ser pinçada da obra — - e da resposta da escritora fixou-se em mim a sua opinião de que o livro não defende um olhar inocente das mulheres sobre a guerra; na sua trama literária, as mulheres instigam a violência dos homens, ambos são feitos do mesmo fundo, enquanto que na trama cinematográfica de Margarida há a perspectiva de um olhar inocente. No filme de Margarida Cardoso, portanto, conforme a opinião de Lídia Jorge, as mulheres ocupam uma posição contemplativa em relação ao conflito; já nas páginas do romance, elas estão envolvidas nele, mesmo distantes do front.

Eis o ponto da palestra de Lídia que inspirou este trabalho: a forma com que a diretora Margarida Cardoso interpretou e transpôs a atuação (ou a falta dela), diante do conflito, das mulheres retratadas na obra original, trazendo para o foco a protagonista Eva Lopo, Evita.

\section{Um curta-capítulo sobre o cinema português}

Antes de ingressar na análise do filme $A$ costa dos murmúrios, em relação à obra que lhe serviu de argumento, é interessante falar um pouco sobre o cinema português, pois importa contextualizar o meu objeto, principalmente em relação ao tema, a guerra colonial, tão importante - e controverso - para o povo lusitano. Esse delicado mote não é dos mais assíduos nas telas portuguesas; a lista de produções que o aborda de forma direta pode não passar de dez ${ }^{1}$. Na opinião de António-Pedro Vasconcelos, Margarida Cardoso e João Botelho, três diretores que colocaram a guerra colonial no cinema, "os portugueses não olham para as feridas do passado" ${ }^{2}$.

\footnotetext{
${ }^{1}$ O Jornal de Notícias, de Portugal, em matéria sobre o assunto, cita os filmes: Angola na guerra e no progresso, de Quirino Simões, produzido em 1971 pelo Serviço de Informação Pública das Forças Armadas e pelo Ministério da Defesa Nacional; Sambizanga, de 1973, filmado clandestinamente em Angola por Sarah Maldoror; logo a seguir do 25 de abril, António-Pedro Vasconcelos rodou Adeus, até ao meu regresso, documentário; e na mesma lógica documental, Fernando Matos Silva dirigiu, em 1980, Acto dos feitos da Guiné. A ficção sobre o tema foi inaugurada somente em 1985, com Um adeus português, de João Botelho; em 1990, Manoel de Oliveira dedica um dos três episódios de Non, ou a vã glória de mandar à guerra; e ainda, Inferno, de Joaquim Leitão, realizado em 1999. Durante todo esse período, vem da Guiné-Bissau um bom exemplo de filme sobre a guerra colonial, vista do outro lado, com E a morte o negou, de Flora Gomes. Em 2003, saiu, de António-Pedro Vasconcelos, Os imortais; no mesmo ano José Carlos de Oliveira filmou Preto e branco, e fechando a lista, em 2011 Margarida Cardoso adaptou o romance de Lídia Jorge A costa dos murmúrios. Esta matéria, publicada em 21 de dezembro de 2006, não cobre o lançamento do documentário Quem vai à guerra, lançado em 2011 pela diretora Marta Pessoa. Disponível em http://www.jn.pt/PaginaInicial/Interior.aspx?content_id=585104

${ }^{2}$ Publicado em Lusa/Notícias em 7 de fevereiro de 2011. Disponível em http://noticias.sapo.pt/especial/guerra_colonial/1128124.html
} 
O cinema feito em Portugal possui características que o determinam como cinema português, rótulo que em muito pode limitar a visão do público estrangeiro e do qual muitos diretores portugueses de determinadas gerações tentaram libertar suas produções. A respeito da discussão sobre o que é português no cinema português, e acima disso, sobre a necessidade de haver uma cara portuguesa nas produções cinematográficas do país, Maria do Rosário Lupi Bello informa as duas tendências para as quais tendem as respostas:

(...) por um lado, a opinião, cada vez mais clara (...), sobretudo por parte de alguns cineastas do cinema "de arte" ou "de autor", acerca da vacuidade de tal tentativa dada a marca de variedade e originalidade que se afigura como predominante na produção cinematográfica feita em Portugal — e, por outro lado, uma irreprimível e recorrente indagação (...) acerca da possibilidade de encontro de uma (ou mais) linha(s) caracterizadora(s) da Sétima Arte portuguesa, como se a busca dessa eventual "portugalidade" fosse condição sine qua non para a adequada compreensão e contextualização de cada objecto cinematográfico do nosso País ${ }^{3}$.

Para Lupi Bello, “nenhuma destas duas 'resoluções' de abordagem ao cinema feito em Portugal esclarece uma especial tendência para fazer do cinema o 'lugar' de uma permanente reflexão sobre o próprio País e a própria cultura (...)" ${ }^{4}$. Essa incansável prática da autorreflexão pode afastar uma população (e um público) ansiosa por diluir-se na globalização e ver nas telas seus conterrâneos colocando o sotaque à disposição de temas universais, em que os espaços cada vez menos se demarcam e os conflitos cada vez mais se compartilham. Tiago Baptista pontua:

É certo que o facto de tantos filmes portugueses se alimentarem da "questão nacional" sugere uma característica comum (e uma identidade partilhada) desta cinematografia. Mas esta característica comum dificilmente poderia ser apontada como uma originalidade do cinema português - e este é outro ponto que tem recebido pouca (ou nenhuma) atenção nas análises mais recentes. Desde pelo menos a década de dez que muitas outras cinematografias na Europa também se tornaram progressivamente reconhecíveis enquanto parte de uma dada cultura nacional e muitas delas desenvolveram mesmo estilos distintos ou especializaram-se em determinados gêneros cinematográficos ${ }^{5}$.

Relacionando essa característica a uma verificada escassez de público para as produções portuguesas, Lupi Bello lança a questão: “existe, ou não, uma relação entre um certo modo de reflectir cinematograficamente o nosso País e uma maior ou menor adesão, por parte do público, a esse olhar? ${ }^{6 "}$ Mais ainda, e pertinente ao tema de As costas dos

\footnotetext{
3 “A implosão do cinema português: duas faces de uma mesma moeda”, em P: Portuguese Cultural Studies 3 Spring 2010, p. 19.

${ }^{4}$ Idem, p. 20.

5 "Nacionalmente correcto: a invenção do cinema português", em Estudos do século XX, Hipóteses de século, 9 , p. 2.

6 "A implosão do cinema português: duas faces de uma mesma moeda", em P: Portuguese Cultural Studies 3 Spring 2010, p. 20.
}

Anu. Lit., Florianópolis, v.18, n. 2, p. 69-83, 2013. ISSNe 2175-7917 
murmúrios, esse pensar-se e repensar-se português, característico do cinema português, envolve o pensar e repensar-se colonizador? E o pensar e repensar o outro, colonizado?

Conforme Lupi Bello, e sua descrição dos caminhos do cinema português, nos anos 40, a produção era

ausente de problematicidade, relativamente pouco ambiciosa, satisfeita por traduzir correctamente (tanto enquanto retrato social como enquanto objecto cinematográfico) o quotidiano popular de uma sociedade que, nos seus hábitos, gostos e humor, se assumia claramente "portuguesa"?

Nos anos 50, embora não apareçam alterações no cenário, “começam a surgir filmes que tratam a questão de África, obviamente enquadrada numa perspectiva colonial" ${ }^{\prime 8}$. A novidade vem mesmo nos anos 60, trazidas por "obras de ruptura, que introduzem a estética da 'nouvelle vague' francesa" ${ }^{9}$ e por inovações, não apenas estéticas, mas, segundo Lupi Bello, temáticas,

onde é visível a passagem de uma abordagem "colectiva" (em que cada filme procurava ser, a seu modo, "Portugal") para uma abordagem "singular" - não apenas porque cada filme procura espelhar o sentir do seu específico "autor", mas também porque (e é este aspecto que aqui mais nos interessa) começa a surgir a tentativa de que, ao contrário do habitual, passe a ser o caso individual - e não o comunitário - o foco de interesse da intriga. ${ }^{10}$

Já para Bapstista, "apesar da renovação das fórmulas gastas e da condenação do cinema de estúdio dos filmes anteriores, o 'cinema novo’ não conseguiu interessar os públicos com as suas metáforas mais ou menos óbvias sobre a contemporaneidade portuguesa" ${ }^{11} \mathrm{e}$, ainda, "foi incapaz de abandonar a "questão nacional",12.

Com a década de 70 e o seu 25 de abril, o cinema português é politizado e vive "uma tumultuosa época de indefinições e desejo de novidade (...), se caracteriza pelo tom panfletário da maior parte dos filmes, mantendo e acentuando também a temática africana (embora de sinal contrário ao anterior) ${ }^{\natural 13}$.

Nos anos 80, o apelo do mercado pesa, e apesar de a temática política manter-se e a postura autorreflexiva insistir, Lupi Bello considera esse peso como a "origem de um desejo de uma maior e mais 'ligeira' ficcionalização, a qual, aliando-se à tentativa de conquista de

\footnotetext{
${ }^{7}$ Idem, p. 21.

${ }^{8}$ Idem, p. 22.

${ }^{9}$ Idem, ibidem.

${ }^{10}$ Idem, ibidem.

11 "Nacionalmente correcto: a invenção do cinema português", em Estudos do século XX, Hipóteses de século, 9 , p. 8 .

12 Idem, ibidem.

13 "A implosão do cinema português: duas faces de uma mesma moeda", em P: Portuguese Cultural Studies 3 Spring 2010, p. 24.
}

Anu. Lit., Florianópolis, v.18, n. 2, p. 69-83, 2013. ISSNe 2175-7917 
um público mais alargado, levou à aposta em filmes de entretenimento e acção (...)"14 Baptista coloca o dilema identitário denunciado pelos filmes realizados numa época em que "a Europa representava tudo aquilo que o país queria ser, ao mesmo tempo que lhe recordava tudo aquilo que não era" ${ }^{15}$. Para o autor, as produções realizadas nos anos oitenta carregam a marca do sentimento dos seus diretores "em relação a um país que amavam e ao qual sentiam pertencer, mas que ao mesmo tempo os sufocava e com o qual, muitas vezes, tinham dificuldade em relacionar-se" 16 .

A partir dos anos 90, até atualmente, para Lupi Bello, essa vontade de conquistar novos públicos afastou os diretores portugueses do tom documental, "deslocando-os para obras mais ficcionalizadas e elaboradas" ${ }^{\prime 17}$, entre as quais poderemos, mais adiante, tentar enquadrar A costa dos murmúrios, de Margarida Cardoso, uma obra adaptada de um romance e de grande efeito estético, portadora também da identidade portuguesa, mas agora dada pelo ponto de vista do outro - no caso, a mulher. Por outro lado, contemporaneamente, esse "ímpeto autocrítico (...) veio a dar origem a um número muito significativo de filmes chamados 'realistas' (cuja designação valeria a pena questionar), onde predomina a cultura (sub)urbana e marginal, feita de depressão e tragédia (...)"18. Ambas as alternativas, em muitos casos, desgostam o público português, incapaz de se enxergar retratado tão violento ou tão marginal. Baptista corrobora que o cinema da década de noventa é inundado "de presente e de realidade", com filmes "ancorados no seu próprio tempo" e indiferentes às reflexões sobre o que é especificamente português. Para o crítico, "quando os filmes portugueses mergulharam de cabeça no presente e descobriram tudo o que ele não tinha de especificamente português (e era muito), conseguiram escapar pela primeira vez às armadilhas de um 'cinema nacional", ${ }^{\prime 19}$.

O que se percebe, seguindo esse breve percurso da história cronológica do cinema português, é que, mesmo estetizando a experiência, trazendo novos olhares e/ou infligindo à tela a violência dos nossos tempos, Portugal mantém a necessidade de olhar para si e acomodar em suas salas de cinema o pequeno e o grande país que é, até mesmo quando o objetivo é justamente abandonar-se ao encontro do outro. Para Tiago Baptista,

\footnotetext{
${ }^{14}$ Idem, p. 25.

15 "Nacionalmente correcto: a invenção do cinema português", em Estudos do século XX, Hipóteses de século, 9, p. 12.

${ }^{16}$ Idem, ibidem.

17 "A implosão do cinema português: duas faces de uma mesma moeda", em P: Portuguese Cultural Studies 3 Spring 2010, p. 26.

${ }^{18}$ Idem, ibidem.

19 "Nacionalmente correcto: a invenção do cinema português", em Estudos do século XX, Hipóteses de século, 9, p. 14.
} 
o que constituía exactamente o país e, mais especificamente, o que devia integrar as suas representações cinematográficas, pode ter sido diligentemente posto em causa por realizadores e críticos a partir de dado momento; mas a premissa de que os filmes portugueses deviam continuar a reflectir de alguma maneira sobre a identidade cultural portuguesa não só era mais antiga e mais estruturante do que se pensava, como permaneceu inabalável até muito recentemente ${ }^{20}$.

Assim, mesmo diante de produções como A costa dos murmúrios, em que o trabalho artístico está colocado visivelmente acima de um hipotético panfletarismo a respeito do que a diretora pensa ou espera de seu país, a questão portuguesa está presente com toda a sua força, desde a escolha da obra a ser adaptada - uma das poucas que lida tão cruamente com o tema da guerra colonial e com a culpa de uma nação. Lupi Bello lança a questão que não respondo, mas que norteia a análise que aqui realizarei: "Se já não é o circunstancialismo político da ditadura a justificar o tom desesperançado e céptico que predomina no nosso cinema, onde encontrar as raízes de tal tom insistente?"21.

\section{A costa dos murmúrios de Lídia Jorge}

A costa dos murmúrios tem como tema a guerra colonial portuguesa, traçada pelas linhas tênues da memória de Evita, uma jovem recém-casada que acompanha o marido à Moçambique, onde ele deve cumprir serviço militar. Quando Luis, o noivo, parte para uma operação que prevê finalizar a guerra, Evita fica sozinha no hotel Stella Maris, palco de mulheres e crianças que, através da espera e de seus significados, participam do conflito.

"Os gafanhotos" é o relato que abre o romance, narrando de forma sucinta, em forma de conto, os acontecimentos de vinte anos atrás. Lá, a noiva Evita está diante do noivo Luis, no terraço do hotel Stella Maris, admirando, junto a convidados embriagados por álcool e êxtase, a África amarela que se estende sob seus olhos, um convite à aventura, à excitação, à violência selvagem em seus diversos níveis de consciência.

Na segunda parte do livro, Eva Lopo, a mulher amadurecida, reconstrói as memórias que se esmaeceram, mas nunca a abandonaram, desde que deixou o hotel, a espera e a África, há vinte anos. Todos os fatos narrados em "Os gafanhotos" de forma redonda, um conto planejado e bem executado, voltam para serem perseguidos e dissecados pela fala crítica e autocrítica de Eva; autocrítica tão profundamente vincada na frase que se repete como um mantra nas cenas mais cruciais de sua rememoração: "Evita era eu".

Uma das coisas mais impressionantes de se ler em A costa dos murmúrios, é saber que Lídia Jorge esteve lá, lecionando em Moçambique enquanto acompanhava o marido

\footnotetext{
${ }^{20}$ Idem, p. 2.

21 "A implosão do cinema português: duas faces de uma mesma moeda", em P: Portuguese Cultural Studies 3, Spring 2010, p. 27.
}

Anu. Lit., Florianópolis, v.18, n. 2, p. 69-83, 2013. ISSNe 2175-7917 
militar. Em sua palestra na PUCRS, a escritora mencionou a emblemática chuva dos gafanhotos. Mais do que a imagem, os sons da festa dos moçambicanos que assavam os insetos em fogueiras, por todo canto, e o escárnio dos oficiais e suas esposas, que a tudo assistiam das janelas do hotel, nunca a abandonaram. Com o tempo, os sons se transformaram em murmúrios que a habitaram até o dia em que decidiu transformar em literatura o seu fragmento vivido - e ainda vívido - de história. Paulo de Medeiros, a respeito da obra, afirma:

Antes de mais, as memórias d'A costa dos murmúrios são memórias de guerra. Guerra colonial, sem dúvida, mas também uma espécie de guerra entre indivíduos, entre homens e mulheres, entre um tempo passado e um tempo presente que, embora inegavelmente constituído pelo passado, não pode evitar recriar continuamente esse mesmo passado ${ }^{22}$.

Evita vive suas memórias vinte anos após os acontecimentos, e como disse Medeiros, são memórias que em muito ultrapassaram a guerra, ou ainda, apenas a atravessaram como quem atravessa um cenário. Um cenário que interage com a história, e em muitos momentos a define, mas ainda assim um cenário. Paula Jordão aponta uma "ambiguidade inesperada", impressa na personagem Evita/Eva, que muito tem a ver com o traçado deste trabalho, determinado pela fala da própria Lídia Jorge. Para Jordão, a estratégia de “minimalizar" Evita, na figura amadurecida de Eva, significa uma cesura de identidade,

cesura essa provocada pela passagem do tempo e que, originando um 'divórcio'
entre a narradora Eva e a personagem Evita, parece situar Evita num plano de
igualdade com as outras personagens. No entanto, se bem que 'divorciadas,' este
'divórcio' tem em si algo de incestuoso. Apesar de Eva Lopo apresentar o seu
comentário com uma visão do presente, é a perspectiva de Evita que prevalece em
toda a segunda parte de CM $[A$ costa dos murmúrios], quer acerca dos
acontecimentos, quer das personagens ${ }^{23}$.

Desta forma, embora tenhamos Eva Lopo guiando nossa leitura de Evita, é a jovem noiva que se transforma diante de nossos olhos, e são seus valores e modos de agir que dominam a nossa perspectiva. E qual a perspectiva de Evita? É uma mulher inocente diante da guerra, mera observadora, como muitas e muitas vezes somos levados a pensar durante a trama, uma vítima da colonização, uma África? Jordão levanta a hipótese de que a ação de Evita é muito mais o resultado da percepção da perda de sua segurança individual - ao descobrir no noivo, ex-estudante de matemática, um violento colonizador — do que de uma tomada de consciência política - como a vida ao lado das mulheres e filhos de oficiais e ao

\footnotetext{
22 "Memória infinita", em Portuguese Literary \& Cultural Studies 2: Lídia Jorge in other words/por outras palavras, Spring 1999, p. 65

23 "A costa dos murmúrios: uma ambiguidade inesperada", em Portuguese Literary \& Cultural Studies 2: Lídia Jorge in other words/por outras palavras, Spring 1999, p. 50.
} 
lado da população negra deveria suscitar. A alteração do caráter de Luís, como foco do abalo da protagonista, é o que leva Jordão a afirmar que “(...) é essa relação já completamente alterada que nos fornece ainda elementos reveladores não só da dependência de Evita da ordem hegemônica patriarcal, em que essa relação se integra, como também da sua interiorização dessa mesma ordem" ${ }^{24}$. Para Medeiros, a grande questão de Eva Lopo, "embora se possa aplicar alegoricamente à nação, é bem pessoal: o sentido de perda de identidade de Evita $^{25,}$. O autor vai além:

Penso ser necessário ir mais longe e encarar a recusa de Eva em se assumir enquanto sujeito unitário como a recusa mesma da sua identidade prévia. Isto é, Eva Lopo, embora reconheça ter sido Evita e não o disfarce, também necessita de considerá-la como outra personagem, num processo de adaptação ao trauma em que só memórias fragmentárias persistem, ainda que mesmo essas continuamente se diluam $^{26}$.

É claro que o texto de Lídia Jorge não se deixa vencer tão facilmente, e não é possível determinar uma ou outra função para a protagonista em se tratando de trama e metáfora. Enquanto Jordão lembra que, ao utilizar palavras como "pombo," "rã" e "baleia", para descrever Helena e as outras mulheres, "Evita revela um suspeito manuseio fácil de imagens que, num discurso sexista, são utilizadas para situar as mulheres numa situação de inferioridade ${ }^{, 27}$, o que poderia evidenciar a sua concordância com a ordem patriarcal, Sumaya Machado Lima acrescenta que, "em geral, as personagens femininas descritas por Eva Lopo nem nome próprio têm: é a mulher do Astorga, é a mulher do Fonseca, é a mulher do tenente Góis, é a mulher do capitão Pedro Deus, a mulher do piloto Fernandes, a mulher do Ladeira, a mulher do Zurique" 28 , e tudo pode tratar-se de artimanhas da escrita para destacar, imprimir, nunca esquecer a marca de futilidade que esses seres recebem diante da história oficial. Conforme Jordão, “também Evita, ao apresentar-se como figura rebelde e contestatária da ordem vigente em que está inserida, não consegue esconder uma cumplicidade com essa mesma ordem, visível na sua relação de poder com o Outro"29.

Em se tratando da questão do feminino, é o embate entre Evita e Helena o ponto alto da trama. A primeira sempre tenta se espelhar na segunda; tenta deixar clara a sua oposição à

\footnotetext{
${ }^{24}$ Idem, p. 51.

25 "Memória infinita", em Portuguese Literary \& Cultural Studies 2: Lídia Jorge in other words/por outras palavras, Spring 1999, p. 74.

${ }^{26}$ Idem, ibidem.

${ }^{27}$ Idem, p. 57.

28 "Murmúrios do espio: uma leitura sobre o olhar marginal e exilado da escrita de Lídia Jorge e suas personagens femininas em A costa dos murmúrios", em Labirintos: Revista eletrônica do núcleo de Estudos Portugueses, Universidade Estadual de Feira de Santana, 3, $1^{\circ}$ semestre de 2008.

${ }^{29}$ A costa dos murmúrios: uma ambiguidade inesperada", em Portuguese Literary \& Cultural Studies 2: Lídia Jorge in other words, Spring 1999, p. 58.
} 
atitude submissa da segunda, e esses embates causam as grandes ambiguidades sobre a personalidade da protagonista. Evita não aceita esperar trancafiada por Luís, mas repete a história - e o mito — de Helena, ao causar a discórdia entre dois homens. E quando Helena a convida a vingar-se deles, dos opressores, Evita nega o convite, postura que para Jordão, denuncia "seu posicionamento privilegiado de classe, sexo e raça" ${ }^{\text {"30. }}$

Para Paulo de Medeiros, Lídia vai além da simples ambiguidade de sua história estar ou não de acordo com os fatos oficiais, ser ou não contrária ao império colonial e, ainda, ser ou não feminista: "Lídia Jorge não se limita a apresentar a memória, mesmo que pessoal e múltipla, como simples termo de oposição ao discurso da História. Aliás, a memória tanto pode ser usada para contestar a ideologia dominante como para a reafirmar"31.

Lídia Jorge esteve na África durante a guerra colonial. Ela esperou por seu marido militar num hotel, assistindo do terraço às chuvas de gafanhotos, sendo servida por mainatos - inclusive, durante a palestra que assisti na PUCRS, relatou que um dos mainatos cuidava do seu filho com responsabilidade e carinho. Lídia surtou com o escárnio dos brancos diante dos negros que preparavam um banquete de insetos. Mas Lídia deixou vinte anos passarem para registrar a sua memória, o seu fragmento, a sua porta de entrada possível para a compreensão de uma guerra. Lídia, cerca de cinquenta anos depois, diante da plateia, afirma que o filme $A$ costa dos murmúrios não condiz com o romance $A$ costa dos murmúrios num ponto crucial: as mulheres não foram inocentes observadoras.

\section{A costa dos murmúrios de Margarida Cardoso}

A costa dos murmúrios ${ }^{32}$ é um filme dirigido pela portuguesa Margarida Cardoso, lançado em 25 de novembro de 2004, que tem como elenco principal Beatriz Batarda (Evita), Filipe Duarte (Luís), Monica Calle (Helena), Adriano Luz (Jaime Forza Leal) e Luís Sarmento (Alvaro), foi filmado grande parte em Moçambique, local onde Margarida, assim como Lídia Jorge, viveu. Filha de militar, Margarida foi para Moçambique nos idos de 1960, e lá morou por doze anos, em um hotel parecido com o retratado no filme, um lugar no qual só ficavam militares portugueses, o mesmo hotel no qual Lídia Jorge ficou hospedada ao acompanhar o marido ${ }^{33}$.

\footnotetext{
${ }^{30}$ Idem, p. 57.

31 "Memória infinita", em Portuguese Literary \& Cultural Studies 2: Lídia Jorge in other words/por outras palavras, Spring 1999, p. 64.

${ }^{32}$ A COSTA dos murmúrios. Direção: Margarida Cardoso. Argumento: Cédric Basso e Margarida Cardoso. Produção: Maria João Mayer. Portugal, 2004. DVD (115 min).

${ }^{33}$ Retirado da entrevista que a diretora concedeu ao site do Festival do Rio, em 2004: Margarida Cardoso, da ficção ao documentário. Disponível em:
} 
A escolha de Margarida pela adaptação deste romance de Lídia não foi aleatória, e pensar nos seus motivos também faz pensar na relação emocional que envolve a sua criação:

A minha história pessoal está para sempre ligada àquela terra, que foi afinal o local da minha infância, e penso que, por isso, é difícil não querer, com toda a força, responder à pergunta "o que foi que correu tão mal nisto tudo?”. Correu mal para todos, para os africanos, para os portugueses, para todos os que sofreram com o absurdo que foi o colonialismo. Este "absurdo" marcou muitas pessoas da minha idade e fez com que muitos de nós ficássemos para sempre sem pertencer realmente a lugar nenhum. O meu percurso mais íntimo está relacionado com factos históricos, com a guerra colonial, com a revolução de 1974 em Portugal, com o regresso de África, acontecimentos que marcaram e mudaram muitas vidas. Ainda hoje há coisas que me fazem chorar imenso, sem saber porquê, como ver pessoas a fugir, imagens de refugiados, gente a ter que sair das suas terras. (...) Parece que alguma coisa da tua vida ficou para sempre escondida, nas pregas da História, e isso é um pouco angustiante. Acho que foi esta necessidade de procura, que já está presente nos meus documentários anteriores, que me fez adaptar A costa dos murmúrios. Percebi que aquilo que queria procurar estava ali, naquele tempo e naquele lugar ${ }^{34}$.

É tomando como matéria-prima a memória pessoal, portanto, que Margarida desenvolve a sua obra, mesclando-a à já intrigante rede de memórias sobre a qual Lídia posteriormente construiu o seu romance: a escritora esteve na África e vinte anos após a sua experiência escreveu um livro no qual a protagonista Eva igualmente rememora a sua estada no continente. Margarida trabalha, portanto, com a memória da memória, com a escrita da memória, com realidade e ficção entrelaçadas desde a escrita do romance, e para sempre.

De uma obra sinestésica como a de Lídia, Margarida retira as cores, os sons, quiçá os cheiros de seu filme. Embora nunca tão cru, tão violento ou tão explícito em suas cenas de desumanidades bélicas — ou desumanidades rotineiras - quanto o romance, o filme consegue retratar sensações que emanam das páginas do livro, como a decepção gradativa e contínua que Evita sofre em relação à imagem que tinha do noivo até pisar o solo africano. A partir de suas descobertas, que iniciam com a cena da matança dos flamingos, acompanhamos uma atriz de semblante cada vez mais concentrado, (circunstancialmente) curioso, triste, transitando por um cenário no qual a violência selvagem e a humana se fundem, numa substância impossível de retornar seus elementos ao estado puro.

Assim como o romance, o filme $A$ costa dos murmúrios não se define por uma vertente temática. Tanto encontramos a História, com a guerra colonial e seus horrores, quanto a questão da condição feminina e também a do conflito racial. Intrínsecos a esses, estão o indivíduo, a identidade, a solidão, o amor, a fidelidade, a liberdade, a censura, o medo, o real e o imaginário, a verdade e o fragmento.

http://2004.festivaldorio.com.br/cgi/cgilua.exe/sys/start.htm?sid=7\&infoid=325

${ }^{34}$ Retirado da entrevista concedida ao site Buala - Cultura contemporânea africana. Disponível em: http://www.buala.org/pt/afroscreen/consideracoes-sobre-a-costa-dos-murmurios

Anu. Lit., Florianópolis, v.18, n. 2, p. 69-83, 2013. ISSNe 2175-7917 
A costa dos murmúrios é o longa-metragem de estreia de Margarida Cardoso, que até então havia realizado apenas documentários. Além das novas medidas de tempo para realizar um trabalho, a diretora ingressa na ficção tomando como argumento um texto repleto de sentidos que não se entregam facilmente à leitura - quanto menos, imagino, a uma reescritura.

Margarida mantém a voz contemplativa de uma Eva que relembra o tempo em que era Evita. Já nas primeiras cenas, a protagonista aparece afirmando a frase icônica da história: "Evita era eu". Estabelecida esta relação, Margarida transpõe o momento da festa de casamento, a visão da noiva, passiva, sonhadora, surpresa, filtrada por uma lente amarela. Todo esse começo do filme, relacionado ao relato intitulado "Os gafanhotos", corresponde à atmosfera de descoberta e excitação que o livro imprime. Todos dançam, cantam, comem, estão bem-humorados. Os noivos não controlam seus desejos potencializados pela exuberância natural da paisagem.

Eva mantém-se uma personagem fascinante nas telas. Sendo retirada inerte da banheira, enfrentando a matança dos flamingos ao vento, denunciando ao jornal o massacre induzido de negros, percorrendo as ruas de Beira e conhecendo as sagas dos seus habitantes, bebendo no Moulin Rouge, dormindo com o gordo, batendo-se com Helena, ouvindo da boca do oficial Gois toda a barbárie da guerra, sendo emoldurada pelas janelas quadriculadas do hotel Stella Maris - que no filme são releituras de Mondrian e sua arte, levada às últimas consequências do abstrato - Eva, ainda Evita, quanto mais se embrenha na outra realidade do noivo, Luís, mais descobre as muitas realidades do mundo. Lauro António, diretor português, descreve:

O filme de Margarida Cardoso fala do secreto, do íntimo, do que se esconde e do que se revela em segredo, do que se diz e do que se cala, do que se oculta e do que se expõe - da guerra utópica que se mostra e da guerra real que se censura, da notícia críptica que sai e da outra reveladora que não se pode dar à estampa, dos sentimentos que se sentem e se calam, das emoções que se ostentam e mentem, da verdade que é mentira, da mentira que é verdade ${ }^{35}$.

É muito forte, no livro, a interpretação de que Evita foi descobrindo a guerra conforme descortinava a personalidade do noivo. São diversas as cenas em que os dois, em momentos íntimos, entre cenas de sexo, banhos, conversas na cama, discutem a própria experiência que estão vivendo. Evita está sempre a questionar Luís sobre cada passo, cada atitude, cada comentário dele a respeito do capitão que tanto admira e imita — principalmente

\footnotetext{
${ }^{35}$ Blog Cinema e literatura europeia. Disponível em: http://cinemaeliteraturaeuropeia.blogspot.com.br/2009/11/costa-dos-murmurios-do-romance-ao-filme.html
} 
no que tange aos relacionamentos com suas esposas. Há sempre essa ruptura entre o Luís do quarto, que acaricia e toma nos braços com delicadeza a esposa de dentro da banheira, e o Luís da rua, que sorri ao dizimar flamingos. Quando Helena mostra a Evita a série de fotografias de guerra que culmina com Luís segurando uma cabeça empalada, a noiva já estava a caminho daquele momento, já se preparava para ele. A partir dali, a denúncia, a investigação, o mergulho na vida de um povo colonizado, o envolvimento com o jornalista tão indignado e silencioso e silenciado quanto ela, são consequências diretas do gradual e contínuo defloramento de sua alma. Conforme a diretora do filme,

\begin{abstract}
é sobretudo um filme sobre a violência de uma perda. A perda da Evita é sobretudo uma perda identitária, não sabe quem é, ali. O filme acabou por ser o percurso desta mulher que quer tentar perceber e vai cada vez mais e mais longe. Não se aproxima de dentro, ela vai sendo sobretudo influenciada por coisas que lhe são exteriores. E esse percurso acaba de uma forma que não é conclusiva, aliás, não queria e não gosto desse tipo de resolução, num último movimento de libertação ${ }^{36}$.
\end{abstract}

Talvez esta postura é que tenha levado Lídia Jorge a tecer o comentário sobre o olhar inocente das mulheres do filme. A costa dos murmúrios de Margarida pode ser em qualquer lugar do mundo, em qualquer época, em qualquer guerra. É uma identidade que se constrói cena a cena. A costa dos murmúrios de Lídia é em todo lugar do mundo, mas sobretudo é o local em que o povo português encara sua crueldade, sua arrogância, sua culpa. E ela não abre mão disso.

\title{
Os grandes finais não acabam
}

Lídia afirmou, durante a palestra na PUCRS, que as suas mulheres não eram inocentes diante da guerra. Afirmou, ainda, que elas estimulavam a violência dos maridos. Nos primeiros momentos do livro, Evita, a noiva, parte o bolo com a espada de Luís, trazida por um escravo, em uma bandeja. No filme, o noivo reclama do ar distante da noiva durante a festa, e a diretora, já de saída, imprime a característica contemplativa da personagem, que a guiará por toda a trama. É este o ponto de apoio de Margarida Cardoso: uma Evita levada pela correnteza dos acontecimentos, pela aventura de descobrir-se só num lugar estrangeiro, em que tantas coisas devem ser descobertas. Compreendemos a trajetória de Evita até Eva muito mais através do filme; através do livro, pensamos e repensamos as motivações verdadeiras desta mulher, que tanto pode estar horrorizada com os horrores da guerra, pelos quais seu marido militar é um grande responsável, quanto pode estar injuriada por ver traído o seu sonho de vida ao lado do noivo matemático. A diretora corrobora essa interpretação:

${ }^{36}$ Retirado da entrevista concedida ao site Buala - Cultura contemporânea africana. Disponível em: http://www.buala.org/pt/afroscreen/consideracoes-sobre-a-costa-dos-murmurios 
No livro, Eva aparece como uma mulher muito mais ativa. No meu filme, ela tem aparência espectral, pois não sabe como lidar com a violência, em especial a violência cotidiana, aquela que mudou seu relacionamento com o marido, e que afeta o seu modo de ver as coisas. A África que procuro reconstruir, através dos olhos de Eva é um pouco parecida com a que me vem à lembrança dos tempos em que lá passei. Só me vêm recordações de um lugar de cores esmaecidas, típicas cores de sofrimento ${ }^{37}$.

Essa é a Evita de Margarida e não há problema que assim ela seja. Uma transposição é, acima de tudo, uma criação. A diretora consegue re-criar a protagonista sem matá-la, sem transformá-la em outra, sem permitir que ela escape de uma das interpretações possíveis da Evita de Lídia. Mas é absolutamente necessário que haja sua voz pessoal em sua obra. Para Lauro António, “mantendo-se fiel ao tom, ao ritmo, ao 'tempo', à ironia da distanciação, à amargura dos olhares, à justeza dos gestos incompletos, a realizadora ganhou a batalha da adaptação, impondo uma voz pessoal"38. E é sem dúvida uma voz pessoal que se eleva das cenas. No livro, as janelas do hotel são quadriculadas. No filme, há mondrians quando os noivos dançam, atrás da orquestra, quando os dois casais se unem pela primeira vez, na parede do quarto, por todo o Stella Maris. Esta é a voz de Margarida: a metáfora de um momento de ruptura na vida de Evita e de Portugal, uma ruptura assombrosa, surpreendente, que torna o presente tão abstrato a ponto de não se deixar transparecer o destino.

Há sutilezas do texto que Margarida faz questão de frisar, como o paralelismo entre os negros que engomam as roupas dos brancos no mesmo ambiente em que as brancas passam a ferro seus cabelos. Há cruezas do texto que Margarida faz questão de suprimir, como os flamingos destroçados pelo tiroteio de Luís e Jaime. Ela prefere focar o rosto de Evita e os primeiros sinais da transformação de sua alma. São as escolhas de uma artista ao reescrever a obra de outra artista. Para a própria Lídia Jorge, em entrevista, Margarida Cardoso "inscrevese numa geração de cineastas que, adaptando literatura para cinema, o faz com um ritmo de respeito pelo ritmo literário. Portanto vai ao encontro do cinematográfico mais puro, que é deixar lá dentro o sonho humano" ${ }^{39}$.

A atmosfera de sonho inicia amarela e vai tomando cores até perdê-las todas, na escuridão das últimas cenas de $A$ costa dos murmúrios. De vermelhos e amarelos vibrantes, os mondrians que emolduram Evita terminam azuis tristes e, mais ao fim, transformam-se nas janelas iluminadas desencontradas que ela vislumbra, à noite, do terraço do Stella Maris. Lídia Jorge finaliza duas vezes a sua história, talvez para demonstrar que sabe muito bem que

\footnotetext{
${ }^{37}$ Disponível em: http://2004.festivaldorio.com.br/cgi/cgilua.exe/sys/start.htm?sid=7\&infoid=325

${ }^{38}$ Blog Cinema e literatura europeia. Disponível em: http://cinemaeliteraturaeuropeia.blogspot.com.br/2009/11/costa-dos-murmurios-do-romance-ao-filme.html

39 Disponível em http://www.jornalopcao.com.br/posts/opcao-cultural/somos-inconformados-com-o-mundo
} 
os grandes finais não acabam, ressoam. Na primeira, em "Os gafanhotos", o FIM é impresso em caixa alta, logo após Evita concluir que "infelizmente, muito infelizmente, as guerras eram necessárias para equilibrar o excesso de energia que transbordava da alma" ${ }^{" 40}$. Na segunda, no final do romance propriamente dito, Eva Lopo, um segundo antes de devolver e anular "Os gafanhotos", diz, rindo:

- Deixe ficar aí, suspenso, sem qualquer sentido útil, não prolongue, não oiça as palavras. A pouco e pouco as palavras isolam-se dos objectos que designam, depois das palavras só se desprendem sons, e dos sons restam só os murmúrios, o derradeiro estádio antes do apagamento ${ }^{41}$.

Os murmúrios de um povo colonizado ressoam nos ouvidos daquele que o colonizou. Não há como escapar do desconforto de se estar para sempre no lugar do ser que invade, abusa, toma para si o que mesmo arrancado à força nunca lhe pertencerá. A chuva de gafanhotos não acaba nos olhos de Lídia Jorge, os mainatos nunca param de assar os insetos e, mesmo que ela não tenha rido diante da cena, ela estava do lado dos que riam, e os sons dessas risadas se confundem com os sons da revoada, com os sons dos dentes triturando os corpos descarnados dos bichos, com o som do seu próprio silêncio retumbando durante anos em sua consciência. Lídia não esconde, no livro e na fala, que o voo do gafanhoto em direção à fogueira simboliza a miséria do colonizado tanto quanto a do colonizador e que, entre os colonizadores, entre os homens que riem e as mulheres que riem das risadas dos homens, não há diferenças, não há atenuantes. Mas há uma chance de se refletir e de se reconstruir na história.

Margarida, antes do apagar da tela, concede-nos uma última tentativa de voo de um flamingo ao amanhecer; talvez opondo-se, muito discretamente, ao tom desesperançoso e cético vigente no cinema português na simbólica cor de rosa, talvez registrando com coragem sua leitura pessoal da obra de Lídia Jorge, como fazem os bons diretores mesmo diante das grandes obras e de seus grandes autores.

\section{Referências}

A COSTA dos murmúrios. Direção: Margarida Cardoso. Argumento: Cédric Basso e Margarida Cardoso. Produção: Maria João Mayer. Portugal, 2004. DVD (115 min).

BAPTISTA, Tiago. Nacionalmente correcto: a invenção do cinema português. In: Estudos do século XX, $\mathrm{n}^{\circ} 9$ - Hipóteses de Século. Coordenação: António Pedro Pita e Paulo Granja. Coimbra: Imprensa da Universidade de Coimbra, 2009.

\footnotetext{
40 JORGE, Lídia. A costa dos murmúrios. Lisboa: Publicações Quixote, 1988. p. 38.

${ }^{41}$ JORGE, Lídia. A costa dos murmúrios. Lisboa: Publicações Quixote, 1988. p. 259.
} 
Disponível

em:

http://run.unl.pt/bitstream/10362/5428/1/Nacionalmente\%20correcto_A\%20inven\%C3\%A7\% C3\%A3o\%20do\%20cinema\%20portugu\%C3\%AAs_CEIS20.pdf

JORDÃO, Paula. A costa dos murmúrios: uma ambiguidade inesperada. In: Portuguese literary \& cultural studies 2: Lídia Jorge in other words, Spring, 1999. Disponível em: http://www.plcs.umassd.edu/docs/plcs02/plcs2-pt2.pdf

JORGE, Lídia. A costa dos murmúrios. Lisboa: Publicações Quixote, 1988. p. 259.

LIMA, Sumaya Machado. Murmúrios do espio: uma leitura sobre o olhar marginal e exilado da escrita de Lídia Jorge e suas personagens femininas em A Costa dos murmúrios. In: Labirintos: Revista eletrônica do núcleo de estudos portugueses, Universidade Estadual de Feira de Antana, 3, $1^{\circ}$ semestre de 2008.

http://www.uefs.br/nep/labirintos/edicoes/01_2008/13_artigo_sumaya_machado_lima.pdf

LUPI BELLO, Maria do Rosário. A implosão do cinema português: duas faces de uma mesma moeda. In: P: Portuguese Cultural Studies, 3, Spring, 2010. Disponível em:

http://www2.let.uu.nl/solis/psc/p/PVOLUMETHREEPAPERS/BELLO-P3.pdf

[Recebido em fevereiro de 2013 e aceito para publicação em outubro de 2013]

From Evita to Eva Lopo, from Lídia Jorge's novel to Margarida Cardoso's film: the adaptation of a unadaptable character

Abstract: This article had its main argument brought up by Lídia Jorge's speech during the lecture given on September 28, 2012 at 7:30p.m. in the auditorium of building 9 at Pontifícia Universidade Católica do Rio Grande do Sul (PUCRS). The author spoke to the audience about the film adaptation for her novel The Murmuring Coast (1988), executed by the director, also Portuguese, Margarida Cardoso (in 2004 ). When she was asked about the female perspective on the colonial war - one in many of the thematic perspectives that can be picked from the work - Lídia confronted the two works, arguing that the book does not advocate/endorse one innocent look from the women at the war, while in the film plot, a prospect of deliverance from guilt is presented. Given this starting point, this analysis aims to examine how the director, Margarida Cardoso, interpreted and adapt the women acting, portrayed in the original work, considering the main conflict of the plot, focusing on the protagonist Eva Lopo, Evita.

Keywords: The Murmuring Coast. Portuguese literature. Portuguese cinema. Lídia Jorge. Adaptation.

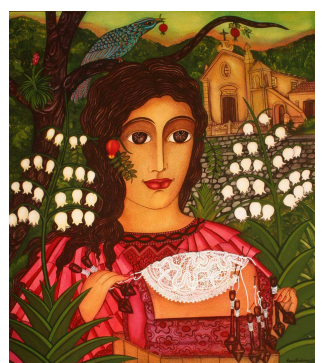

